\title{
Exploitation and utilization of renewable energy resources in rural areas of western China
}

\author{
Yong-hua Wang ${ }^{1)}$, Guo-liang Luo,a), Cheng-feng Long ${ }^{3)}$ \\ ${ }^{1,2,3}$ School of Economics and Management, North China Electric Power University, Beijing, 10026, \\ China
}

Key words:Rural energy; Renewable energy resource; Energy poverty; Western China rural areas Abstract: Western China is confronting two urgent problems, rural poverty and environmental deterioration. The development of renewable energy boasts great potential to solve these two problems. In addition, developing renewable energy in rural areas of western China may result in several benefits, including meeting rural energy demands, protecting the environment, and promoting rural development. In 2007, about one million rural households had no access to electricity in Western China, and traditional biomass energy was dominant for cooking. Western China boasts plentiful renewable energy sources and utilizing these will be an effective way to alleviate energy poverty. The Chinese government's renewable energy projects implemented in rural areas of Western China have received attention, but barriers still exist in developing renewable energy. Therefore, strong support through appropriate budgets, taxes, credits and finance assistance from the government, encouragement in private investment for more financing channels, and the establishment of a complete rural energy service system are necessary. This paper examines the development of the exploitation of renewable energy resources.

\section{Introduction}

The past 30 years have witnessed the fastest rate of economic development in the history of the People's Republic of China (PRC). Accounting for 19\% of the world's population, the nation of 1.34 billion people has transformed from primarily agrarian to highly industrialized. This rapid change and growth is expected to continue, and will be accompanied by economic, environmental, and social problems that other countries have experienced during industrialization. However, in the $\mathrm{PRC}$, because of the rapid changes and the population, these changes are occurring in a much more concentrated and intense manner than what has been experienced elsewhere.

The PRC is the world's largest producer and consumer of energy. While the country as a whole depends largely on coal and oil, nearly $50 \%$ of its 200 million rural households in 2008 still relied on burning firewood and various agricultural waste to heat their homes and cook their meals, which poses a serious hazard to the environment and health [1]. In particular, energy security in rural areas, rural environmental challenges, and urban-rural inequality are constraints on the government's ability to achieve its socioeconomic development objectives. Ultimately, the country must rebalance its economic development so that its rural population, agricultural sector, and environment can also benefit from this growth. To achieve this, it was found that the government must invest in rural energy, particularly renewable energy [2]. No developed country has significantly reduced poverty and sustained growth without improving households' access to energy. 
Different from traditional energy classification, rural energy mainly refers to energy production and consumption in rural areas of developing countries. Specifically, production energy consumption includes the consumption of agricultural production and rural enterprises, the consumption of energy associated with living include cooking, heating, lighting and household appliances, and the energy consumption of household vehicles. Energy production mainly refers to the production of renewable energy in rural areas.

Rural energy is an important resource and material base for developing rural production, ensuring agricultural living and improving rural environments. The consumption of rural energy is closely related to regional energy security, soil deterioration, air pollution, rural poverty and change of living modes [3]. How to utilize rural energy and power to relieve energy poverty becomes a focus for energy research in developing countries [4-12].

However, sufficient attention has not been paid to the production of renewable energy in China's rural areas and the energy consumption of rural residents. Problems including energy shortages, deforestation, low-capacity coal mining, and rural indoor air pollution have troubled the production, living and ecology of Chinese rural areas. Due to research data restrictions, most literature only describe China's energy poverty situation and energy production and consumption of rural energy [13-19], and fail to examine how to utilize rural renewable energy resources.

The paper consists of six parts. The first part examines <what is the first part that you are referring to?> The second part discusses current renewable energy resources in rural areas of Western China. The third part focuses on energy consumption and its influence in rural areas of Western China. The fourth part analyzes the modes for exploitation and use of renewable energy. The fifth part examines the obstacles and actions for developing renewable energy resources in rural areas and conclusions are presented in the sixth part.

\section{Renewable energy resources in Western China}

Western China boasts a vast total area, plentiful energy resources, and advantageous renewable energy resources (see Table 1). Every western province can store renewable energy resources. However, reserves vary greatly due to seasonality, influencing the exploitation of renewable energy.

Table1.Renewable energy resources in rural areas of Western China [20,21]

\begin{tabular}{|c|c|c|c|}
\hline Wind energy resource & Solar energy resource & Hydro energy resource & Biomass resource \\
\hline $\begin{array}{l}\text { In Xinjiang, Gansu, } \\
\text { Ningxia provinces and } \\
\text { the Inner Mongolia } \\
\text { Autonomous Region of } \\
\text { Western China, the } \\
\text { average annual wind } \\
\text { power density is } \\
200-300 \mathrm{~W} / \mathrm{m}^{2}, \text { and } \\
\text { exceeds } 500 \mathrm{~W} / \mathrm{m}^{2} \text { in } \\
\text { some areas. }\end{array}$ & $\begin{array}{l}\text { Western China has rich } \\
\text { solar energy resources. } \\
\text { The richest solar resource } \\
\text { area }\left[\mathrm{kWh} / \mathrm{m}^{2} \geq 1750 \text { per }\right. \\
\text { year] makes up } 42.7 \% \text { of } \\
\text { China's land mass. The } \\
\text { second-richest solar } \\
\text { resource area }\left[\mathrm{kWh} / \mathrm{m}^{2} \text {. }\right. \\
1400-1750 \text { per year] } \\
\text { makes up around } 17.4 \% \\
\text { of China's land mass. }\end{array}$ & $\begin{array}{l}\text { Hydro energy } \\
\text { resources in Western } \\
\text { China account for } \\
81.6 \% \text { of the total of } \\
\text { the country. The total } \\
\text { electricity } \\
\text { development of small } \\
\text { hydro-power } \\
\text { enterprises below } \\
50 \mathrm{MW} \text { in China is } \\
128 \mathrm{MW} \text { of which } \\
\text { Western China } \\
\text { accounts for } 62 \% \text {. }\end{array}$ & $\begin{array}{l}\text { There are } \\
\text { abundant crop } \\
\text { stalks, firewood } \\
\text { and animal waste } \\
\text { in Southwest } \\
\text { China suitable for } \\
\text { developing } \\
\text { biogas. }\end{array}$ \\
\hline
\end{tabular}




\section{Energy consumption in rural areas of western China and its influence}

Part A: Characteristics of energy consumption for living in rural areas in western China

Profiles of the eastern, central and western regions of China are elaborated in Table 2.

Table 2.Profile of the eastern, central and western regions of China(2010)

\begin{tabular}{|c|c|c|c|}
\hline Region & Coverage & $\operatorname{Area}\left(/ 10,000 \mathrm{~km}^{2}\right.$ & $\begin{array}{c}\text { Rural Population } \\
(10,000) \\
\end{array}$ \\
\hline Eastern & $\begin{array}{l}\text { Beijing, Tianjin, Hebei, Liaoning, } \\
\text { Shanghai, Jiangsu, Zhejiang, Fujian, } \\
\text { Shandong, Guangdong, Hainan }\end{array}$ & 106.8 & 22708.51 \\
\hline Central & $\begin{array}{l}\text { Shanxi, Jilin, Heilongjiang, Anhui, } \\
\text { Jiangxi, Henan, Hubei }\end{array}$ & 166.8 & 23538.12 \\
\hline Western & $\begin{array}{l}\text { Inner Mongolia, Guangxi, Chongqing, } \\
\text { Sichuan, Guizhou, Yunan, Shaanxi, } \\
\text { Gansu, Qinghai, Ningxia, Xinjiang }\end{array}$ & 565.2 & 22249.17 \\
\hline
\end{tabular}

In 2007, rural China had a population of about 727.5 million, and most used traditional biomass energy due to economic and technical restrictions. The energy consumption structure in different rural areas varies due to differences in geographical locations, economic and cultural conditions. The structure and differences among eastern, central and western China in living energy consumption indicate that rural area's living energy consumption in western China is different from that found in eastern and central China, however there are some similarities in basic features of living energy consumption in rural areas.(see details in Table 3)

Table3. Living energy consumption structures in eastern, central and western rural areas in China $(10,000 \mathrm{~kg}$ ce)

\begin{tabular}{|c|c|c|c|c|c|c|c|c|c|}
\hline & \multicolumn{3}{|c|}{ Eastern China } & \multicolumn{3}{|c|}{ Central China } & \multicolumn{3}{|c|}{ Western China } \\
\hline & Total & $\begin{array}{l}\text { Commo } \\
\text { dity } \\
\text { energy }\end{array}$ & $\begin{array}{c}\text { Non- } \\
\text { commod } \\
\text { ity } \\
\text { energy }\end{array}$ & Total & $\begin{array}{l}\text { Commodit } \\
\text { y energy }\end{array}$ & $\begin{array}{c}\text { Non- } \\
\text { commodity } \\
\text { energy }\end{array}$ & Total & $\begin{array}{l}\text { Commodit } \\
\text { y energy }\end{array}$ & $\begin{array}{c}\text { Non- } \\
\text { commodity } \\
\text { energy }\end{array}$ \\
\hline רחק & 12162 & 3228 & 8934 & 11095 & 2456 & 8639 & 13154 & 2617 & 10537 \\
\hline 2002 & $100 \%$ & $26.5 \%$ & $73.5 \%$ & $100 \%$ & $22.3 \%$ & $77.9 \%$ & $100 \%$ & $19.9 \%$ & $80.1 \%$ \\
\hline 2007 & 13038 & 4854 & 8184 & 13125 & 2875 & 10250 & 14245 & 2991 & 11254 \\
\hline 2007 & $100 \%$ & $37.2 \%$ & $62.8 \%$ & $100 \%$ & $21.9 \%$ & $78.1 \%$ & $100 \%$ & $21.0 \%$ & $79.0 \%$ \\
\hline $\begin{array}{l}\text { Growth } \\
\text { from } \\
2002 \text { to } \\
2007\end{array}$ & $7.2 \%$ & $50.3 \%$ & $-8.4 \%$ & $18.3 \%$ & $17.0 \%$ & $18.7 \%$ & $8.3 \%$ & $14.3 \%$ & $6.8 \%$ \\
\hline
\end{tabular}

Note: Commodity energy includes coal, electricity, LPG, natural gas, biogas and fuel. Non-commodity energy includes firewood and straws. Data was acquired from the website http://www.ocpe.com.cn/.

Between 2002 and 2007, non-commodity energy accounted for about $80 \%$ of living energy consumption in rural areas of western China, which was higher than that in other regions during the same period.

\section{Structure of energy consumption with traditional biomass energy as the dominant source}

The main reasons for the higher consumption and proportion of non-commodity energy in rural western China were relatively laggard economic development, underdeveloped traffic, and high logistics costs associated with this region. With continuous increases in the demands of family energy consumption, rural residents prefer to use free or cheap biomass energy.

When examining cooking fuels, traditional energy use in rural households is the highest in 
western China, i.e. 66.2\%. (See Table 4).

Table4.Cooking fuels consumption proportion in different rural areas in 2013 (unit: \%)[22,23]

\begin{tabular}{ccccc}
\hline Category & $\begin{array}{c}\text { National } \\
\text { average }\end{array}$ & Eastern China & Central China & Western Chin \\
\hline Firewood & 50.2 & 43.1 & 46.5 & 53.5 \\
Coal & 22.1 & 12.6 & 28.4 & 26.7 \\
Coal gas and & 14.9 & 37.1 & 15.9 & 12.1 \\
natural gas & & 0.2 & 2.0 & 2.1 \\
Biogas & 5.3 & 7.0 & 6.2 & 5.1 \\
Electricity & 6.8 & 0.0 & 0.0 & 0.5 \\
Others & 0.7 & &
\end{tabular}

\section{Large gaps between western China and central and eastern China in rural energy consumption} and service

In 2002, non-commodity energy in rural living energy consumption in eastern, central and western China were all above $70 \%$, and the difference among these three regions was less than $8 \%$. In 2007, with the rapid rise of commodity energy in rural areas of eastern China, its proportion of total energy consumption surged to $37.2 \%, 16.2 \%$ higher than that found in rural areas of western China. The growth rates of rural living energy consumption and quantities of commodity energy in central China were both higher than those found in western China. The disparity in commodity energy between eastern and western China was apparent in rural living energy consumption. Based on the current commodity energy development speed, the commodity energy proportion in rural living energy consumption of central China will keep increasing. The gap between central and western China in commodity energy consumption will be further increased.

Over the long-term, the dual structure resulting from the segmentation of urban and rural areas in China has caused rural areas to drastically lag behind the urban areas in infrastructure construction including electrical facilities. Generally speaking, China's low level of rural electrification is well documented. Great regional gaps exist in rural electricity consumption and grid development. The per capita annual electricity consumption in eastern China is five to six times that found in the central and western regions of China. As for rural annual per capita living electricity consumption, gaps among provinces and municipalities are also quite large. In 2014, the national average per capita living electricity consumption is about $289 \mathrm{kWh}$, while the leading consumption was $634 \mathrm{kWh}$ in Beijing, over 6.6 times higher than that in Tibet [Table 5].

Table5 Living electricity '2014 consumption in rural areas of Western China (unit:kWh)[22]

\begin{tabular}{ccc}
\hline Regions & $\begin{array}{c}\text { Living electricity } \\
\text { consumption per household }\end{array}$ & $\begin{array}{c}\text { Per capita living electricity } \\
\text { consumption }\end{array}$ \\
\hline Sichuan & 1303.8 & 286.8 \\
Guangxi & 999.3 & 249.8 \\
Guizhou & 914.4 & 228.6 \\
Shaanxi & 826.4 & 206.7 \\
Inner Mongolia & 815.7 & 203.5 \\
Ningxia & 867.4 & 211.3 \\
Xinjiang & 717.7 & 149.2 \\
Gansu & 728.6 & 151.6 \\
Qinghai & 763.5 & 188.5 \\
Yunnan & 619.6 & 166.2 \\
Tibet & 627.3 & 95.9 \\
\hline
\end{tabular}


The main characteristics of energy poverty in rural areas of Western China include no access to power supply in a number of households in remote mountainous regions, and use of traditional biomass energy for cooking in most households.

At the end of 2007, about one million rural households, mainly in western areas (see Table 6), had no access to electricity. The rural households without access to electricity were distributed mainly in areas served by the Sichuan Electric Power Corporation, State Grid Corporation of China and China Southern Power Grid [1].

The areas without access to electricity served by Sichuan Electric Power Corporation were distributed mainly in Garze, Daba and Liangshan prefectures and remote mountainous counties (cities, districts), totaling 369,900 households in 3,884 villages (1,983 villages had no power access at all) of 1,226 townships in 77 counties (cities, districts) in 13 cities (prefectures).

The State Grid Corporation of China served 192.308 million rural households in 498,235 villages, of which, 250,000 households and 1,694 villages could not reach a power supply, or, 99.87\% households and $99.66 \%$ villages had access to electricity. The China Southern Power Grid served in total 47.614 million rural households of 63,249 villages, of which, 232,800 households and 37 villages (all in Yunnan province) could not reacha a power supply, or, $99.51 \%$ households and $99.94 \%$ villages had access to electricity.

Table 6.Rural households without power access in Western China in 2014[22]

\begin{tabular}{cc}
\hline Regions & Rural households $(10,000)$ \\
\hline Tibet & 6.06 \\
Yunnan & 1.28 \\
Qinghai & 1.16 \\
Sichuan & 0.99 \\
Guangxi & 1.88 \\
Shaanxi & 0.87 \\
Xinjiang & 1.03 \\
Inner Mongolia & 0.13 \\
\hline
\end{tabular}

\section{Low proportion of clean energy consumption and low energy efficiency in western rural areas.}

China has continuously strengthened rural energy construction, launched many projects, and provided funds to adjust rural energy structure and improve modes of rural energy consumption . Although obvious achievements have been made, China stills lags behind developed countries in terms of modes of energy consumption. In 2010, coal and other regular commodity energy accounted for $29.0 \%$, while straw, firewood, and other traditional biomass energy accounted for $37.2 \%$ of China's rural energy breakdown [22]. However, quality clean energy of liquefied gas, natural gas and electricity had lower proportions.

According to statistics, the average living energy consumption of urban residents is over two times higher than that of the rural residents in Western China [22]. Energy statistics only involve commodity energy. Traditional energy consumption of rural residents is not included in commodity energy since traditional energy is autarkic. In fact, the living energy consumption of rural residents may be higher than that of urban residents. A reasonable explanation to this might be the low energy efficiency of rural energy consumption. Regional changes of rural living energy consumption and the per capita energy consumption changes from 2002 to 2014 indicate that the per capita energy consumption in rural areas of western China was higher than that in other regions over the same period (See Table 7). This is mainly attributed to the overwhelming majority of traditional biomass energy in total energy consumption. The proportion of living commodity energy of rural western 
China was lower than eastern and central China.

Table 7.Per capital living energy consumption changes in rural areas of eastern, central and western China(unit: kg ce/a)[22,23]

\begin{tabular}{cccc}
\hline & Eastern China & Central China & Western China \\
\hline 2002 & 554 & 482 & 621 \\
2014 & 236 & 332 & 402 \\
Decline & $-57.4 \%$ & $-31.1 \%$ & $-19.7 \%$ \\
from 2002 to 2007 & & & \\
\hline
\end{tabular}

\section{Part B. Consequences of inefficient energy consumption and services in rural western China}

\section{Resource and environmental problems in rural areas of Western China.}

The low energy use efficiency and outdated modes of energy use in rural China have caused huge resource losses and environmental pollution. Western China, a region with poor natural conditions, was trapped by the vicious cycle of "poverty, excessive development, and ecological degradation" due to its vulnerable ecological environment, large poverty-stricken population and increasingly severe pollution. Excessive ecological damage has become the biggest obstacle to severely restrict local socioeconomic development.

In the PRC, farm incomes are now under pressure due to resource degradation and and agricultural wastes from animals and crops, and their traditional uses are exacerbating problems in rural environments. Environmental problems include desertification, soil erosion, grassland degradation, salinity on irrigated land, organic matter and fertility loss, burning of crop residues, aquifer depletion, high levels of heavy metals, nitrates and pesticide residues in soils and water, animal wastes, and loss of biodiversity.

Most western rural households continue to rely on directly burning coal or biomass, such as crop stalks and firewood, which are typically burned in low-efficiency stoves for cooking, water heating, and space heating. Most crop straw and fuel wood stoves are 2.5 times less efficient than biogas or LPG cookware.

Excessive use of crop residues and firewood also exploits forest resources, which has led to significant environmental damage including deforestation, soil erosion, biodiversity reduction, and damage to watersheds. This practice also makes it difficult to recycle chemical elements (e.g., nitrogen, potassium, and phosphorous contained in crop stalks and firewood into the fields) thus reducing the fertility of the soil. In addition, the practice has a heavy social cost, as women and children carry the burden of gathering fuel and preparing the fire for cooking each meal.

Animal wastes from growing livestock farms are constantly introducing massive quantities of non-point source pollutants to waterways. Based on ADB studies, the rural chemical oxygen demand load in 2001 was 1.42 times the load from industry and urban sewage discharges. By 2020, the study projected that the rate of livestock production will have increased by $167 \%$ that of the 2000 levels. A 40\% reduction in rural nonpoint source pollution by 2020 will be needed to stabilize pollution at its current high levels, which poses a considerable challenge to livestock producers [2].

\section{Inefficient energy consumption leads to severe health loss and inequality.}

Direct combustion of biomass fuels causes serious air pollution and health risks for the PRC's western rural population. Burning traditional biomass continues to be a major cause of indoor air pollution and respiratory disease in the PRC's western rural areas. Fluoride poisoning is a common health problem in Guizhou province, where some 1.9 million poor farmers are affected, mostly women, children, and the elderly, often from minority ethnic groups, because of inequitable gender 
roles in the house and inequitable access to efficient stoves or household biogas systems [2].

Every year, about 420,000 Chinese people die from indoor air pollution caused by solid fuel combustion. Respiratory disease has been one of the four major diseases leading to deaths of rural residents over the long-term (see Table 8), and has accounted for $18 \%$ of disease-caused deaths in rural areas each year, with higher rates in Western China [14]. If rural cooking ranges become comparably energy efficient to urban ones, the mortality caused by respiratory disease will decline $32 \%$. If urban residents consume clean energy instead of traditional biomass energy, the chronic bronchitis of rural children and adults will decrease $80 \%$ and $45 \%$, respectively [14].

Table 8 Proportion and ranking of respiratory disease-caused death of China's rural residents [14]

\begin{tabular}{ccccccccccc}
\hline Year & 2000 & 2001 & 2002 & 2003 & 2004 & 2005 & 2006 & 2007 & 2008 & 2009 \\
\hline $\begin{array}{c}\text { Proportion in } \\
\text { disease-caused } \\
\text { death }\end{array}$ & 23.1 & 22.5 & 15.6 & 18.7 & 13.3 & 23.5 & 16.4 & 17.2 & 16.9 & 15.0 \\
Rank & 1 & 1 & 1 & 3 & 3 & 3 & 1 & 3 & 3 & 4 \\
\hline
\end{tabular}

Use of traditional fuels for cooking with pollution and the opportunity cost of gathering them imposes back breaking labour and a time-consuming job on people, particularly women and young girls. Poor households tend to spend more time collecting these fuels than those from higher-income groups. The need to gather fuels may deprive young girls from schooling. This 'hard earned' energy is used very inefficiently, converting only about $15 \%$ of the total into useful energy [22]. Use of such inefficient and polluting fuels, over time, increases the risks of eye infections and respiratory diseases and it affects the health of women and the girls more adversely, as they spend more time indoors and are primarily responsible for cooking. In farming and pastoral areas of Tibet, the average time for a woman to collect biomass is 1.5 hours, and the time spent using traditional biomass to cook is 2.5 hours .

\section{Modes for exploitation and use of renewable energy in rural western China}

Decentralized and centralized developments are the two major modes for renewable energy development in rural western China areas.

\section{A. Decentralized development}

Decentralized development is a popular mode of traditional energy development in rural China. In comparison with cities, most rural areas are characterized by a weak economic base, sparse population, laggard infrastructure, inaccessibility to public services, and relatively poor resources. Rural residents often have special firewood rooms or stack firewood and straws directly in their yards. Straws and firewood are the main sources for rural living energy consumption. This traditional decentralized energy consumption complies with the lifestyle and housing condition of rural residents and boasts a lower cost. Renewable energy sources suitable for decentralized development are mainly solar photovoltaics, biogas, and straw gasification. Rural areas have inborn conveniences in building solar cookers, solar water heaters, and small biogas pits.

Solar water heaters can be directly installed on roofs in rural areas, which is simple to install and low in cost. Decentralized household biomass pits often work in a recycling mode in combination with the rural household's breeding situation. Straws and livestock and poultry manure are materials for producing biogas. Then the biogas produced is used for cooking, lighting and other living energy consumption. And the biogas slurry and residues can be used to fertilize the land or raise pigs, fish and poultry. 


\section{B. Centralized development}

Centralized development mode refers to the energy production center and users are connected via a transmission network while the energy production and consumption are isolated. In this mode, production and supply are independent. Centralized energy production in modern factories are carried out to obtain a scale effect and management advantages. Renewable energy users do not need to consider the production and maintenance of energy. Centralized energy development may result in a scale economy of energy production and service. However, the construction cost for the energy transmission network is high. Its operation is also limited by the sources and markets of rural renewable energy raw materials.

Different development modes may be applied for the same energy in different areas or at different development stages. Decentralized development mode is applicable to sparsely-populated areas with laggard infrastructures, and centralized development modes to densely-populated renovated rural areas with rapid progress in new rural construction, which are rural areas in eastern China with complete infrastructures, service systems, relatively developed economy, and high urbanization level.

\section{Renewable energy projects implemented in western rural areas "Light Project"}

In September 1996, responding to the "Light Project" initiative of global non-interconnected areas, the Chinese government launched the Chinese Light Project, aiming at offering electricity to remote areas by means of wind energy and solar energy power supply systems. The National Planning Committee then developed the Action Plan for Phase I of Chinese Light Project in consideration of the West Development strategy, preparing a five-year investment of about 10 billion yuan by national and local budgetary appropriations to solve the power supply problem for about 1.80 million farming and herding households and 2000 administrative villages .

\section{"Electricity access to villages" project}

In 2002, the Chinese government initiated the "Electricity access to villages" project to build more than 720 off the grid PV power stations in seven western provinces (Tibet, Qinghai, Xinjiang, Sichuan, Inner Mongolia, Gansu and Shaanxi). The Central Government made different appropriations to different provinces, such as $100 \%$ appropriation to Tibet, $80 \%$ to Qinghai and $20 \%$ by the local government, $50 \%$ to Xinjiang, Sichuan, Inner Mongolia, Gansu and Shaanxi and $50 \%$ by the local governments. The appropriations by the Central Government and the local governments amounted to about 1.8 billion yuan. The "electricity access to villages" project has provided 1.3 million people from about 300 thousand households in rural western China with access to electricity for basic living, and has alleviated energy poverty in the region [24,25] .

\section{“Golden Sun” Project}

Prior to 2008, PV power generation had been mainly used in off-grid projects, such as off-grid power stations in non-electric areas, household power supply, communication, meteorology, railways, and solar energy street lamps. By the end of 2010, the loaded capacity of off-grid PV power generators had reached $16 \mathrm{MW}$, up $20 \%$ from the previous year [19].

In order to drive the development of the domestic photovoltaic power generation market, the Ministry of Finance, National Energy Board and Ministry of Science jointly launched the "Demonstrative Building Integrated Solar PV Project" and the "Golden Sun" Project in 2009 to support decentralized photovoltaic power generation by lump sum subsidies. The "Demonstrative Building Integrated Solar PV Project" and the "Golden Sun" Project have provided large amounts of energy to drive large-scale promotion of domestic photovoltaic power generation. By the end of 
2012, the projects included in the scope of subsidies provided 6455MW. Between 2009 to 2012, the subsidy scale provided by the "Demonstrative Building Integrated Solar PV Project" and the “Golden Sun" Project are shown in Table 9.

Table 9.The subsidy scale of "Demonstrative Building Integrated Solar PV Project" and "Golden Sun" Project between 2009 to 2012

\begin{tabular}{llllllll}
\hline & \multicolumn{1}{c}{ Year } & & 2009 & 2010 & 2011 & 2012 & Total \\
\hline $\begin{array}{l}\text { "Demonstrative } \\
\begin{array}{l}\text { Project"(MW) } \\
\text { "Golden Sun" Project (MW) }\end{array}\end{array}$ & Integrated & Solar PV & 90 & 100 & 110 & 225 & 525 \\
& & & & & & \\
\hline
\end{tabular}

\section{Replacing regular fuels with electricity from small hydropower stations}

Since reform and opening, the Chinese government has attached great importance to the role of small hydropower stations in rural social and economic development. The Central Government has allocated special funds raised through national debt issuance to support local governmental development of small hydropower stations each year and carried out the hydropower-electrified counties in five consecutive Five-year plans (1985-2010). The country's policy and fund support greatly inactivate the local governments and people's motivation in developing small hydropower stations. During 1995-2000, the 410 hydropower-electrified counties had completed an accumulated investment of 115.1 billion yuan, and increased installed capacity of 1,060MW for hydropower, or $3 \mathrm{MW}$ increase for each county.

In 2003, in order to solve energy demands of residents in areas where grain plots were converted to forestry, the Chinese government carried out a special pilot project to replace fuel energy with small hydropower in areas with rich small hydropower resources (5MW and below), high population density, and an urgent demand for alternative fuels, especially in Western China, to protect the ecological environment and promote sustainable development. The project involved more than 200,000 rural residents in 26 counties of Sichuan, Yunnan, Guizhou, Guangxi and Shanxi, covering 1.56 million mu of natural forest reserves, natural reserves and key soil erosion rehabilitation regions with a gross investment of 280 million yuan. In 2006, the Chinese government expanded this special project in 80 counties (cities) of 21 provinces (autonomous regions, municipalities), benefiting 636,000 rural residents from 169,000 households with a total investment of 1.03 billion yuan. In 2007, China had 1,528 counties equipped with small hydropower stations, including 584 counties with hydropower as the main power supply, and invested 1.44 billion in rural hydropower grid renovations [22].

The Renewable Energy Law of the PRC enforced in 2006 profoundly influenced the development of renewable energy in China. A range of economic incentives like financial subsidies and direct financial investments greatly promoted and bolstered the development of renewable energy, playing a critical role in eliminating rural energy poverty and boosting electrification in rural China. In April 2010, the Renewable Energy Law of the PRC-Amended stipulated to consolidate electricity price add-ons and national special financial funds into national renewable energy development funds to support renewable energy utilization in rural and pasturing areas and the construction of separate renewable energy power systems in remote areas and on islands. National renewable energy development funds offer legal and financial support to the electrification of rural and pasturing areas unfit for grid extension due to restrictions of natural conditions and geographic locations.

\section{Deviations in exploitation and utilization of renewable energy in rural western China}

The selection of the mode of energy development is a comprehensive consideration of the level 
of economic development, consumption power, residence environment, living habits, and infrastructure situation (See Table 10). Infrastructures, a sort of public services, normally require great investment and are restricted by local economic development. In rural areas with developed economies, farmers have sufficient economic power and can afford relatively expensive sources, such as LPG or electricity instead of firewood for cooking. In rural areas with high economic development, infrastructure is more complete and the living environment is more suitable for centralized energy development. On the contrary, regions with low economic development are not suitable for centralized energy development concerning living environment and infrastructure development. Decentralized development is the only choice for these regions.

Table 10.Comparison of renewable energy development modes

\begin{tabular}{llc}
\hline Items & Decentralized & Centralized \\
\hline Infrastructures & Poor & Complete \\
Investment scale & Small & Moderate \\
Service requirement & Low & High \\
Market scale & Small & Large \\
Energy solutions & Solar energy, straw gasification, Wind energy, small hydropower \\
& biomass, small hydropower stations, biomass, straw \\
& stations & gasification \\
\hline
\end{tabular}

Rural regions in eastern China have a relatively developed economy and society, rapid urbanization, more complete social infrastructure and higher farmer's income in comparison with central and western China. On the contrast, rural western China is underdeveloped, with incomplete infrastructure, low urbanization and population density, and laggard living conditions, which indicate that rural western China is currently suitable for decentralized energy development. Practices also prove that most renewable energy projects in western China are developed in a decentralized mode and have received recognition of international communities and organizations.

In recent years, large-scale centralized development has been applied for the exploitation and utilization of renewable energy in western China, such as China's ambitious plan for seven wind power bases. But China's emphasis and support for decentralized development have been insufficient. Nearly a million rural households are without power access. Requirements for farmer's living and power demands in western China are often neglected. The rights of local residents regarding public service and equitable development are not given sufficient consideration in the development and utilization of renewable energy in western China.

\section{Obstacles and actions for developing renewable energy resources in rural western areas}

\section{A. Obstacles for developing renewable energy resources in rural western areas}

Obstacles for developing renewable energy resources in rural western areas are summarized as follows.

Firstly, there is to date no effective and professional electricity regulation. As the regulator of the electricity market, State Electricity Regulatory Commission (SERC) regulates electricity enterprises, electric dispatching transactions, and fair and open power grids. The Renewable Energy Act has clearly regulated that power grid enterprises should provide connecting services of electricity generation by renewable energy, and construct and manage the integration system of renewable energy power generation projects. In practice, the power grid enterprises have failed to carry out the above regulations, while SERC has not taken effective measures. Due to no effective 
and professional electricity regulation, the overall grid connection of renewable energy power is difficult to implement, which has led to serious consequences. In 2011, the wind curtailment percentage of Western China is about 20\%, and the wind curtailment power exceeds 7500MWh [23]. This lack of effective and professional electricity regulation leads to the waste of renewable energy resources of Western China.

Secondly, incentive policies for renewable energy development are not effectively performed. Over the long-term, the on-grid price for electricity from small hydropower stations has been low. In 2010, the national average on-grid price for electricity from small hydropower stations was only 0.28 yuan $/ \mathrm{kWh}$, from thermal power plants was 0.36 yuan $/ \mathrm{kWh}$, from nuclear power plants was 0.50 yuan $/ \mathrm{kWh}$, from wind power farms was $0.55 \mathrm{yuan} / \mathrm{kWh}$, and from solar power plants was 1.09 yuan/kWh. The low on-grid price for electricity from small hydropower stations did not reflect the country's policy of encouraging the development of renewable energy [23]. In addition, due to the restriction of management systems, grids for transmitting electricity from small hydropower stations in remote areas of central and western regions have not been incorporated into the nationwide rural grid renovation. Areas in central and western regions not covered by the rural grid renovation involve 6.82 million people from 1.82 households in 5,420 villages, 904 townships, 184 counties in 19 provinces (autonomous regions). Most of these areas are former revolutionary base areas, areas inhabited by ethnic groups, remote and border areas and poverty-stricken areas with underdeveloped economies, poor geographical environments and scattered populations, which result in difficulty and high costs for rural grid construction and renovation, and high costs for the operation and maintenance of small hydropower enterprises [22]. These factors restrict the sustainable development of small hydropower stations in rural areas of Western China.

Thirdly, financing means are limited. Investment and financing for renewable energy projects in rural China are largely for governmental demonstration projects for public benefit, lacking formal institutional arrangement, special investment, and financing systems. Rural areas in Western China have complicated geographical environments, high difficulty acquiring power access (see Table 11), and increasing investment risks. As for economic and technical feasibility, the development of renewable energy has some advantages in alleviating and solving energy poverty in rural western China. Due to the restrictions of the underdeveloped economy, financial straits, slow rural income increases, limited investment modes and financing channels for rural renewable energy construction projects, and lack of improved incentive policies in financing, taxing and pricing, a number of challenges exist. These include promotion, transport, installation, training, maintenance and management processes related to the application of separate renewable energy power generation equipment in rural areas of Western China. This means that releasing and eliminating rural energy poverty will be a tough fight.

Table 11 Cost of power access for nonelectric households in rural areas of Western China between 2006 and $2014[22,23]$

\begin{tabular}{ccccccccc}
\hline Year & 2006 & 2007 & 2008 & 2009 & 2011 & 2012 & 2013 & 2014 \\
\hline $\begin{array}{l}\text { 1000yuan/h } \\
\text { ousehold }\end{array}$ & 1.01 & 1.27 & 1.25 & 1.42 & 1.45 & 1.41 & 1.39 & 1.37 \\
\hline
\end{tabular}

Limited financing channels and insufficient funds become main obstacles for biogas development in China (Table 12). Household biogas development in rural China mainly depends on the Central Government's subsidies and the household's self-raised funds. Local governments offer relatively low funds for biogas development. Currently, the household biogas investment in rural areas of Western China is about 5,800 yuan, only $24 \%$ of which is from the Central Government. 
The apparently low subsidy to rural biogas projects from the Central Government results in low-quality biogas projects and a decreasing utilization ratio, and has a negative influence on sustainable development.

Table12 Investment of biogas in China [22]

\begin{tabular}{|c|c|c|c|c|c|c|c|c|c|}
\hline \multirow[t]{2}{*}{ Year } & \multirow{2}{*}{$\begin{array}{c}\begin{array}{c}\text { Total } \\
\text { investment }\end{array} \\
\begin{array}{c}(100 \mathrm{mil} \\
\text { yuan })\end{array}\end{array}$} & \multicolumn{2}{|c|}{$\begin{array}{c}\text { Household biogas } \\
\text { projects }\end{array}$} & \multirow{2}{*}{\multicolumn{2}{|c|}{$\begin{array}{c}\text { Small biogas } \\
\text { projects } \\
\text { Qty. } \\
\text { Invest. } \\
\text { (Site)(100mil } \\
\text { yuan) }\end{array}$}} & \multicolumn{2}{|c|}{$\begin{array}{c}\text { Medium and large } \\
\text { biogas projects }\end{array}$} & \multicolumn{2}{|c|}{ Service outlets } \\
\hline & & $\begin{array}{l}\text { Qty. } \\
(10,000 \\
\text { household }\end{array}$ & $\begin{array}{l}\text { Invest. } \\
(100 \mathrm{mil} \\
\text { s) yuan) }\end{array}$ & & & $\begin{array}{r}\text { Qty. } \\
\text { (Si }\end{array}$ & $\begin{array}{c}\text { Invest. } \\
\text { 00mil } \\
\text { yuan) }\end{array}$ & $\begin{array}{l}\text { Qty. } \\
\text { (Sites) }\end{array}$ & $\begin{array}{c}\text { Invest. } \\
\text { (100mil } \\
\text { yuan) }\end{array}$ \\
\hline 2001 & 1.3 & 16.5 & 1.2 & - & - & 17 & 0.1 & - & - \\
\hline 2002 & 3.1 & 28.6 & 2.9 & - & - & 49 & 0.2 & - & - \\
\hline 2003 & 10.3 & 103.3 & 10.2 & - & - & 24 & 0.1 & - & - \\
\hline 2004 & 10.3 & 104.4 & 10.1 & - & - & 20 & 0.2 & - & - \\
\hline 2005 & 10.3 & 104.6 & 10.1 & - & - & 10 & 0.2 & - & - \\
\hline 2006 & 25.4 & 261.0 & 25.0 & - & - & 44 & 0.4 & - & - \\
\hline 2007 & 25.4 & 249.6 & 24.0 & 882 & 0.3 & 39 & 0.5 & 4472 & 0.8 \\
\hline 2008 & 60.0 & 419.8 & 49.0 & 9271 & 2.5 & 187 & 1.8 & 40903 & 6.7 \\
\hline 2009 & 50.0 & 165.6 & 23.8 & 2885 & 1.6 & 1579 & 17.6 & 18140 & 7.0 \\
\hline
\end{tabular}

Fourth, the investment in research and development is insufficient. Insufficient investment in technological development restricts the innovation ability of renewable energy sources in Western China. Compared with the national investment in many demonstrative promotion projects, the investment in scientific and technological research related to biogas, wind power, solar energy in the western area over the last 10 years are obviously insufficient. Many R \& D institutions and manufacturing enterprises are reluctant to introduce new products, technologies and materials due to lack of funds. Many key devices for developing renewable energy sources must be imported. This results in slow development and low industrialization and commercialization.

Fifth, the lagged development of social services restricts the efficiency of the utilization of renewable energy sources in rural western area. Using biogas as an example, in the last two years, China has made a total investment of about 1.4 billion yuan in the construction of rural biogas service stations. However, due to a lack of funds for operation, many service stations have difficulty surviving [26]. Due to the lack of effective services, the biogas digesters cannot be effectively used. This is a pervasive problem in rural western area, which also exists in the small wind power systems and solar photovoltaic power generation systems.

\section{B. Actions for developing renewable energy resources in rural western areas}

We provide several suggestions to remove obstacles for the development of renewable energy sources in rural western areas.

The first is to establish effective regulations for renewable energies. Effective and professional renewable energy regulations are an important base and premise of developing and utilizing renewable energy resources. First, the function of the National Energy Administration (NEA) for managing the sustainable energy sources industry in a unified way should be strengthened at the same time as establishing effective coordinating mechanisms among different departments to clearly define specific responsibilities and execution procedures of related departments and solve the problems in cross authority and omissive responsibilities. Second, a rural and urban renewable 
energy sources management system should be established to enhance the construction of the rural standard systems for sustainable energy technologies and products, systems for functional specification, testing and certification and systems for services related to the energy and the industry. This would promote the improvement of basic conditions for rural residents to use energy and ensure the safety of rural energy consumption. In addition, to socially manage resources and the environment related to the development of renewable energy sources in rural areas, explicit regulations should be made.

The second is to adopt diversified economic incentive policies and financing mechanisms. At the initial stage of the project of renewable energy sources in rural western areas, the rural residents may have to make an unaffordable investment. Therefore, a number of economic incentive policies should be adopted to increase the on-gride price of small hydropower supply, provide subsidies for terminal renewable energy source products and operation of enterprises engaged in manufacturing related products and equipment and make and carry out policies for tax relief. The application of technologies using renewable energy sources brings large social and environmental benefits. For this reason, the Chinese government should provide compensation for rural residents. Meanwhile, the rural financial service system should be gradually improved to serve rural residents in a comprehensive way with rural cooperative financial institutions, policy-based financial institutions, postal savings banks and joint-stock financial institutions. The rural financial business should be opened up, and rural residents should be encouraged to fund and develop small hydropower, small wind power, and small PV system projects of their own free will and under the support of the government.

The third is to expand investment in development technologies related to renewable energy sources in rural western area.

Rural western areas have slow development, with insufficient financial strength. Therefore, the government should emphasize this area when providing policy support for the construction of new countryside. During the new round 10-year Western Development, the government should expand its investment in infrastructure building and development of technologies related to renewable energy sources, and promote technologies related to renewable energy sources in rural western areas. Thus far, China has fully developed a number of technologies and products for using renewable energy sources, such as comprehensive biogas utilization, small hydropower, solar photovoltaic system, and small-scale wind power generation technologies. These will be helpful for improving life and living conditions of the farmers and herders in rural western areas and finally solving the energy utilization problems.

In addition, to solve bottleneck problems in this field, the government should organize research institutions and innovative new energy enterprises to cooperate with each other to make key breakthroughs by executing key research projects and developing new technologies, processes, products and materials that meet the overall conditions and have prospects.

The fourth is to establish a renewable energy service system in rural western areas. The construction of a first-level rural energy service network should be enhanced to solve problems in promoting the use of renewable energy in rural areas. A number of such service suppliers with integrated functions for technical training, planning and design, purchase of materials, construction and installation, quality control and service after construction should be fostered. Great efforts should be made to put the renewable energy source projects into practice featuring professional construction, property-based management and socialized services. 


\section{Conclusions}

Lagging infrastructure and public service systems in rural areas of Western China restrict the development of the local economy and incomes of local farmers and herdsmen. When examining energy consumption in this area, the traditional biomass energy constitutes the highest proportion, while clean energy is insufficient. Most of China's households without access to electricity are distributed in remote mountainous areas of western China. Therefore, there is still a long way to go to relieve or eliminate energy poverty in this area.

Rural western areas have abundant renewable energy sources. Develop and utilizing these energy sources is an effective way to relieve or eliminate the energy poverty, and increase farming and herding employment opportunities and income.

In general, in rural western areas, establishing effective regulation for renewable energies is the important base and premise of developing and utilizing renewable energy resources. It is urgently to adopt diversified economically incentive policies and financing mechanisms. Investment in development technologies related to renewable energy sources must be expanded and a renewable energy service system must be established.

\section{References}

[1] Luo GL, Zhang XH. Universalization of access to modern energy services in Tibetan rural households-Renewable energy's exploitation, utilization, and policy analysis. Renewable and Sustainable Energy Reviews 16(6),2373-2380(2012).

[2] Liu XY, Comparative analysis of urban and rural biogas development modes, China Population. Resources and Environment 20 (3),302-310(2010)

[3] Tonooka Y, Liu JP, Kondou Y. A survey on energy consumption in rural households in the fringes of Xi'an city. Energy and Buildings 38(11), 1335-1349(2006).

[4] S.Pachauri,A.Mueller, A.Kemmler,D.Spreng. On measuring energy poverty in Indian households. World Development 32(12), 2083-2095(2004).

[5] Ren DM, New policy saved new energy? Energy Review 6,114-123(2010).

[6] Marcio, Giannini Pereiraa, Marcos Aurélio. The challenge of energy poverty: Brazilian case study. Energy Policy 39(1), 1679-1693(2009).

[7] Ranjan Parajuli. Access to energy in Mid/Far west region-Nepal from the perspective of energy poverty. Renewable Energy 36(9), 2299-2311(2011).

[8] Anjali Bhide, Carlos Rodríguez Monroy. Energy poverty: A special focus on energy poverty in India and renewable energy technologies. Renewable and Sustainable Energy Reviews 15(2), 1057-1070(2011).

[9] Zhang XL, Ashok Kumar. Evaluating renewable energy-based rural electrification program in western China: Emerging problems and possible scenarios. Renewable and Sustainable Energy Reviews 15(1), 773-784(2011).

[10] Makoto Kanagawa, Toshihiko Nakata. Assessment of access to electricity and the socio-economic impacts in rural areas of developing countries. Energy Policy 36(6), 2016-2027(2008).

[11] de Jong P, Sánchez AS, Esquerre K, Kalid RA, Torres EA. Solar and wind energy production in relation to the electricity load curve and hydroelectricity in the northeast region of Brazil. Renewable and Sustainable Energy Reviews 23, 526-535 (2013) . http://dx.doi.org/10.1016/j.rser.2013.01.050 .

[12] Sánchez AS, Kalid RA, Torres EA. Renewable energy generation for the rural electrification of isolated communities in the Amazon Region. Renewable and Sustainable Energy Reviews 49, 278-290 (2015) . 
[13] Tonooka Y, Mu H L, Ning Y D. Energy consumption in residential house and emissions inventory of GHGs, air pollutants in China. Journal of Asian Architecture and Building Engineering 2(1), 93-101(2003).

[14] Jin Y L, Ma X, Chen X N. Exposure to indoor air pollution from household energy use in rural China: The interactions of technology, behavior, and knowledge in health risk management.Social Science and Medicine 62(12), 3161-3175(2006).

[15] Wei Y M, Liu LC, Fan Y. The impact of lifestyle on energy use and $\mathrm{CO}_{2}$ emission: An empirical analysis of China's residents. Energy Policy 35(1),247-259(2007).

[16] Li K, Liu CF, Wei YM. Analysis on China's current energy poverty. Energy of China $8,1-5(2011)$.

[17] Xie ME,Study on energy poverty and energy projects in rural areas with backward development but rich resources. Economic Research Guide 77(3), 29-37(2010).

[18] Qiao SQ, Study on development of alternative energy sources in China's western poverty-striken areas. Journal of Agrotechnical Economics (4), 78-85(2010).

[19] Liu J, Zhu LZ, Study on the energy consumption of the Chinese rural households. Journal of Agrotechnical Economics (4), 35-43(2010).

[20] Yuan,J H,Xu Y. Managing electric power system transition in China. Renewable and Sustainable Energy Reviews (16), 5660-5672(2012).

[21] Wang, ZH Y, Ren,R M. The Renewable Energy Industrial Development. Energy of China (12), 1-7(2013).

[22] Chen,Q,Yang H R, Liu T B.Household biomass energy choice and its policy implications on improving rural livelihoods in Sichuan,China.Energy Policy93(2016)291-302.

[23] Zheng X Y,Wei Ch,Song F.Chinese household energy consumption research report 2015.Science Press 2016.

[24] Luo G L,GuoY.W.Rural Electrification in China: A policy and institutional analysis. Renewable and Sustainable Energy Reviews (23), 320-328(2013).

[25]Li F, Cheng S K. Waste from livestock and poultry breeding and its potential assessment of biogas energy in rural China.Journal of Cleaner Production126(10),451-462(2016).

[26]Liao H,Tang X,Wei YM.Solid fuel use in rural China and its health effects.Renewable and Sustainable Energy Reviews 60(4), 900-910( 2016). 